\begin{tabular}{|c|c|c|c|c|c|c|c|c|}
\hline \multirow{3}{*}{$\begin{array}{c}\text { Seed } \\
\text { stock }\end{array}$} & \multicolumn{4}{|c|}{ Diploid controls } & \multicolumn{4}{|c|}{ Tetraploid plants } \\
\hline & \multirow{2}{*}{$\begin{array}{l}\text { Total } \\
\text { alka- } \\
\text { loid } \\
\text { per } \\
\text { cent }\end{array}$} & \multicolumn{3}{|c|}{$\begin{array}{l}\text { Percentage ratio of } \\
\text { total alkaloid }\end{array}$} & \multirow{2}{*}{$\begin{array}{c}\text { Total } \\
\text { alka- } \\
\text { loid } \\
\text { per } \\
\text { cent }\end{array}$} & \multicolumn{3}{|c|}{$\begin{array}{l}\text { Percentage ratio of } \\
\text { total alkaloid }\end{array}$} \\
\hline & & $\begin{array}{c}\text { Hyoscy- } \\
\text { amine }\end{array}$ & $\begin{array}{l}\text { Atro- } \\
\text { pine }\end{array}$ & $\mid$\begin{tabular}{|} 
Hyo- \\
scine
\end{tabular} & & $\begin{array}{c}\text { Hyosey- } \\
\text { amine }\end{array}$ & $\begin{array}{l}\text { Atro- } \\
\text { pine }\end{array}$ & $\begin{array}{l}\text { Hyo- } \\
\text { scine }\end{array}$ \\
\hline \multicolumn{9}{|c|}{ Datura Stramonium } \\
\hline $\begin{array}{l}\mathrm{A} \\
\mathrm{B} \\
\mathrm{C}\end{array}$ & $\begin{array}{l}0 \cdot 20 \\
0 \cdot 35 \\
0 \cdot 27\end{array}$ & $\begin{array}{l}81 \\
68 \\
76\end{array}$ & $\begin{array}{r}5 \\
18 \\
8\end{array}$ & $\begin{array}{l}14 \\
14 \\
16\end{array}$ & $\begin{array}{l}0.55 \\
0 \cdot 50 \\
0.50\end{array}$ & $\begin{array}{r}82 \\
.78 \\
75\end{array}$ & $\begin{array}{r}6 \\
8 \\
12\end{array}$ & $\begin{array}{l}12 \\
14 \\
13\end{array}$ \\
\hline \multicolumn{9}{|c|}{ Datura tatula } \\
\hline$\vec{A}$ & $0 \cdot 24$ & 83 & nil & 17 & $0 \cdot 40$ & 85 & nil & 15 \\
\hline
\end{tabular}

alkaloidal contents to those of the parental tetraploid plants. The provisional conclusion may thus be drawn that the percentage total alkaloidal contents of tetraploid plants of $D$. Stramonium and $D$. tatula are approximately double those of the diploid plants; while the proportions of the individual alkaloids present remain unchanged.

Assays of tetraploid and diploid material from other species of Datura and from species of Atropa and Hyoseyamus are not yet completed. It is hoped to publish a detailed account of these researches when the results of the 1944 growing season have been obtained.

Depts. of Botany and of Pharmacy,

J. M. Rowson.

University, Manchester. June 19.

\section{Relation of the Concentration of Vitamin A, Carotenoids and Cholesterol in Milk Fat to the Size of the Fat Globules}

Some time ago, Henry et al. ${ }^{1}$, in measuring the vitamin $\mathbf{A}$ and carotene content of samples of fat churned or extracted by solvents from the same bateh the different stages of butter-making. In some of these experiments cheese was also prepared from the same bulk of milk and similar measurements were made on the whey, and at the different stages of butter-making from whey. Samples obtained during the separation by gravity of cream from milk were also examined. The results quoted in the accompanying table may be taken as an example. It shows that although the vitamin A was substantially the same in all fractions, the fat of separated milk contained seven times and the fat of separated whey eleven times as much carotenoids as the original milk fat. These two fractions consisted of the smallest fat globules which were not removed by two centrifugings in a dairy separator. The concentration of carotenoids in the fat of buttermilk and in the fat of whey was also higher than in the original milk, though the difference was very much less marked. Measurements-showed that the size of the fat globules of these fractions was intermediate between that of the globules of the original milk and that of the separated milk. It will be seen that a very close correlation exists between the amounts of carotenoids and of cholesterol in the various fat fractions. Our values for cholesterol are of the same order as those reported by Frengley and Herrick ${ }^{3}$ and by Ansbacher and Supplee ${ }^{4}$ in similar fractionation experiments. Iodine values of the fatty acids prepared from the fats varied little, but were somewhat higher in the fats from separated milk and separated whey.

The difference in behaviour between vitamin $\mathrm{A}$ and carotenoids is very striking. The uniform concentration in which the former occurs in the different fat fractions suggests that it may be in true solution in the fat. The carotenoids and cholesterol, on the other hand, are present in greater amounts in those fractions in which the ratio of fat globule surface to fat is higher, and therefore may be associated in some way with the fat globule membrane.

Further work on these problems is in progress.

\begin{tabular}{|c|c|c|c|c|c|c|c|}
\hline Fraction & $\begin{array}{l}\text { Method of } \\
\text { extraction } \\
\text { of fat }\end{array}$ & $\begin{array}{c}\text { Fat } \\
\text { (gm. per } \\
100 \text { ml.) }\end{array}$ & $\begin{array}{l}\text { Vitamin A } \\
\text { (I.U. per } \\
\text { gm. fat) }\end{array}$ & $\begin{array}{l}\text { Carotenoids } \\
(\mu \mathrm{gm} . \text { per } \\
\mathrm{gm} . \mathrm{fat})^{* *}\end{array}$ & $\begin{array}{l}\text { Cholesterol } \\
\text { (mgm. per } \\
\text { gm.fat) }\end{array}$ & $\begin{array}{l}\text { Iodine value } \\
\text { of fatty acids }\end{array}$ & $\begin{array}{l}\text { Average radius of } \\
\text { fat globules (mean of } \\
200 \text { measurements) }\end{array}$ \\
\hline $\begin{array}{l}\text { Milk } \\
\text { Cream } \\
\text { Separated milk } \\
\text { Butter } \\
\text { Buttermilk } \\
\text { Whey } \\
\text { Whey cream } \\
\text { Separated whey } \\
\text { Whey butter } \\
\text { Whey buttermilk }\end{array}$ & $\begin{array}{l}\text { Solvent* } \\
\text { Solvent* } \\
\text { Solvent* } \\
\text { Churning } \\
\text { Solvent** } \\
\text { Solvent* } \\
\text { Solvent* } \\
\text { Solvent* } \\
\text { Churning } \\
\text { Solvent* }\end{array}$ & $\begin{array}{c}3 \cdot 14 \\
35 \cdot 35 \\
0 \cdot 06 \\
86 \cdot 90 \dagger \\
1 \cdot 98 \\
0 \cdot 42 \\
18 \cdot 20 \\
0 \cdot 03 \\
83 \cdot 90 \dagger \\
2 \cdot 25\end{array}$ & $\begin{array}{l}24 \cdot 7 \\
25 \cdot 3 \\
21 \cdot 6 \\
26 \cdot 3 \\
24 \cdot 2 \\
23 \cdot 2 \\
24 \cdot 7 \\
26 \cdot 2 \\
26 \cdot 3 \\
23 \cdot 9\end{array}$ & $\begin{array}{r}9 \cdot 8 \\
9 \cdot 5 \\
65 \cdot 4 \\
9 \cdot 4 \\
12 \cdot 2 \\
14 \cdot 9 \\
9 \cdot 4 \\
111 \cdot 0 \\
9 \cdot 3 \\
12 \cdot 4\end{array}$ & $\begin{array}{r}3 \cdot 3 \\
2 \cdot 8 \\
36 \cdot 0 \\
2 \cdot 5 \\
6 \cdot 0 \\
5 \cdot 6 \\
3 \cdot 3 \\
46 \cdot 0 \\
2 \cdot 7 \\
5 \cdot 3\end{array}$ & $\begin{array}{l}38 \cdot 5 \\
41 \cdot 5 \\
45 \cdot 2 \\
40 \cdot 2 \\
42 \cdot 3 \\
37 \cdot 8 \\
40 \cdot 2 \\
48 \cdot 0 \\
40 \cdot 1 \\
42 \cdot 0\end{array}$ & $\begin{array}{l}1.41 \\
1.68 \\
0.51 \ddagger \\
0 . \overline{89} \\
1.09 \\
1.80 \\
\S \\
\overline{0.84}\end{array}$ \\
\hline
\end{tabular}

* The method was that of Olson et al. ${ }^{2}$ slightly modifled.

$\uparrow$ gm. per $100 \mathrm{gm}$. per cent.

** The percentage of $\beta$ carotene measured by chromatography did not vary greatly in the different fat fractions ; the range was 74-83

$\ddagger$ Only 50 globules measured.

$\S$ Owing to small size and scarcity of the fat globules, satisfactory measurement was not possible.

of milk, found that the concentration of vitamin A was the same in the fats prepared by both methods, but that there was slightly more carotene in the extracted fat. This they attributed to destruction during churning.

We have now obtained substantial evidence to show that this explanation is not correct, and that the small difference was due to the relatively high concentration of carotenoids in that fraction of the original milk fat which remained in the separated milk. We have carried out several experiments in which vitamin $\mathrm{A}$ and carotenoids were measured at
S. K. Kon.

E. H. Mawson.

S. Y. Thompson.

National Institute for Research in Dairying, University of Reading. June 19.

${ }^{1}$ Henry, K. M., Kon, S. K., Gillam, A. E., and White, P., J. Dairy Res., 10 , 114 (1939). 2 Olson, F. R., Hegsted, D. M., and Peterson, W. H.ł J. Dairy Sci.,
22, 63 (1939).

${ }^{3}$ Frengley, M. G., and Herrick, M. M., Bull. N.Z. Dept. Sci. Indust. Res., No. 34 (1931).

‘ Ansbacher, S., and Supplee, G. C., J. Biol. Chem., 105, 391 (1934). 